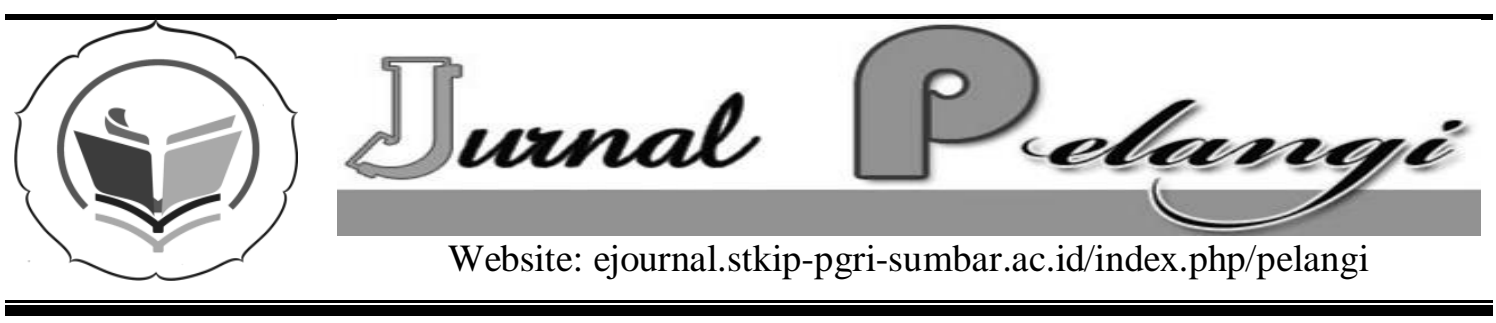

\title{
PENGARUH PENERAPAN MODEL PEMBELAJARAN PROBLEM BASED LEARNING DISERTAI TEKNIK KEPALA BERNOMOR TERHADAP HASIL BELAJAR MATEMATIKA SISWA SMP KELAS VIII
}

\author{
Feby Atika Andri, Tika Septia, Alfi Yunita \\ STKIP PGRI Sumatera Barat \\ febyatikandri@yahoo.com
}

INFO ARTIKEL

Diterima:

1 Agustus 2016

Direview:

27 September 2016

Disetujui:

28 Desember 2016

Kata Kunci:

Problem Based

Learning, Teknik

Kepala Bernomor,

Hasil Belajar

\begin{abstract}
Abstrak
Penelitian bertujuan untuk mengetahui apakah hasil belajar matematika siswa dengan menerapkan model pembelajaran Problem Based Learning disertai Teknik Kepala Bernomor lebih baik daripada hasil belajar matematika siswa dengan pembelajaran konvensional. Jenis penelitian adalah eksperimen dengan rancangan penelitian random terhadap subjek. Populasi pada penelitian ini adalah seluruh siswa kelas VIII SMPN 7 Padang Tahun Pelajaran 2015/2016. Instrumen penelitian adalah tes akhir. Bentuk tes yang digunakan adalah bentuk essay yang reliabel. Teknik analisis data yang digunakan adalah uji t satu pihak. Berdasarkan analisis data dapat disimpulkan bahwa hasil belajar matematika siswa yang menerapkan model pembelajaran problem based learning disertai teknik kepala bernomor sama dengan hasil belajar matematika siswa yang menerapkan pembelajaran konvensional
\end{abstract}

Abstract
The study aims to determine is the result of student mathematic
learning by apllying the Problem Based Learning
accompanied Mechanical Numbered Head learning model is
better than conventional learning model. The type of this
research is experimental research and to collect the data
researcher use random sampling. Population of this research
were all eight grade students of junior high school number 7
Padang. The test form used was essay with reliability $r_{11}=$
$0,92 . \quad$ Data analysis technique used is the t test of the
parties. So it can be concluded that the result of students
mathematics learning at eight class student which is applied
learning model of Problem Based Learning accompanied
Mechanical Numbered Head is same as learning outcomes
math students who aplly conventional learning.




\section{PENDAHULUAN}

Matematika merupakan salah satu ilmu yang mempunyai peranan penting dalam menunjang kemajuan ilmu pengetahuan dan teknologi. Besarnya peranan yang dimiliki matematika disebabkan karena matematika itu bersifat logis dan rasional. Begitu pentingnya peranan matematika, berbagai cara atau usaha yang sudah dilakukan pemerintah agar mutu pendidikan semakin baik sehingga siswa dapat meningkatkan hasil belajar.

Hasil belajar adalah kemampuankemampuan yang dimiliki siswa setelah ia menerima pengalaman belajarnya. Jadi, hasil belajar merupakan hasil yang diperoleh siswa setelah mengalami pengalaman-pengalaman dalam proses pembelajaran serta kemampuan dalam proses pembelajaran. Kenyataan yang ditemukan di SMPN 7 Padang, hasil belajar matematika yang diperoleh siswa belum sesuai dengan harapan.

Berdasarkan observasi dan wawancara diketahui beberapa masalah yang terjadi dalam pembelajaran matematika. Hasil belajar siswa masih dibawah KKM, siswa kurang aktif dalam pembelajaran, kurangnya kerjasama siswa dalam kelompok, kurangnya interaksi siswa dengan guru, dan siswa kurang terampil dalam memecahkan suatu masalah.

Salah satu alternatif untuk mengatasi masalah di atas, maka guru perlu mencoba berbagai model pembelajaran. Salah satu model yang diperkirakan dapat digunakan guru untuk mengatasi permasalahan di atas adalah penerapan model pembelajaran problem based learning disertai teknik kepala bernomor.

Ngalimun (2013:96) mengemukakan bahwa Problem Based Learning merupakan model pembelajaran inovatif yang dapat memberikan kondisi belajar aktif kepada siswa. PBL melibatkan siswa untuk memecahkan suatu masalah mengguna-kan metode ilmiah yang membuat mereka mahir dalam memecahkan masalah, dan memiliki model sendiri serta memiliki kecakapan berpartisipasi dalam tim.

Menunjang fase ketiga pada proses pembelajaran problem based learning maka disertai dengan teknik kepala bernomor. Lie (2002:58). Teknik ini memberikan kesempatan kepada siswa untuk saling membagikan ide-ide dan mempertimbangkan jawaban yang paling tepat. Selain itu teknik ini juga mendorong siswa untuk meningkatkan semangat kerjasama mereka. Penelian ini bertujuan untuk mengetahui apakah hasil belajar matematika siswa kelas VIII SMPN 7 Padang yang pembelajarannya menerapkan model pembelajaran problem based learning disertai teknik kepala bernomor lebih baik daripada pembelajaran konvensional di kelas VIII SMPN 7 Padang.

Pembahasan ini telah dilakukan melalui sebuah penelitian, dan penelitian yang relevan dilakukan oleh Rio Syafyudi Armen (2015) dengan kesimpulan yang diperoleh dari penelitian tersebut yaitu hasil belajar siswa yang menerapkan metode pembelajaran problem based learning sama dengan hasil belajar siswa yang menerapkan pembelajaran konvensional di kelas VII SMPN 2 Linggo Sari Baganti.

\section{METODE PENELITIAN}

Jenis penelitian yang dilakukan adalah penelitian eksperimen dengan rancangan penelitian random terhadap subjek. Populasi dalam penelitian ini adalah seluruh siswa kelas VIII SMPN 7 Padang Tahun Pelajaran 2015/2016. Teknik pengambilan sampel dilakukan secara acak, yang terpilih sebagai kelas eksperimen adalah kelas $\mathrm{VIII}_{1}$ dan sebagai kelas kontrol adalah kelas $\mathrm{VIII}_{2}$. 
Instrumen penelitian ini adalah tes akhir berupa soal esai dengan reliabilitas tes $r_{11}=0,92$ dan $r_{\text {tabel }}=0,404$. Menurut kriteria dalam Depdiknas (2010: 239) instrumen penelitian tersebut reliabel. Teknik analisis data yang digunakan adalah uji t satu pihak.

\section{HASIL DAN PEMBAHASAN}

Berdasarkan hasil analisis data diperoleh gambaran seperti berikut:

Perhitungan yang dilakukan didapat nilai rata-rata $(\bar{x})$, simpangan baku $(\mathrm{S})$, skor tertinggi ( $\left.x_{\max }\right)$, skor terendah $\left(x_{\text {min }}\right)$ tes akhir kelas sampel sesuai dengan Tabel 1.

Tabel 1 memperlihatkan bahwa nilai rata-rata siswa kelas eksperimen lebih tinggi daripada nilai rata-rata siswa kelas kontrol. Simpangan baku kelas kontrol lebih tinggi daripada simpangan baku kelas eksperimen, artinya kemampuan siswa kelas kontrol lebih beragam daripada kelas eksperimen.

Berdasarkan pengujian hipotesis yang menggunakan uji $\mathrm{t}$ satu pihak diperoleh $t_{\text {hitung }}=1,06$. Karena $t_{\text {hitung }}<t_{\text {tabel }}$, dimana $t_{\text {tabel }}=$ 1,665 maka $H_{0}$ diterima dan tolak $H_{1}$, sehingga dapat disimpulkan bahwa hasil belajar matematika siswa dengan menggunakan model pembelajaran Problem Based Learning disertai Teknik Kepala Bernomor sama dengan hasil belajar matematika siswa menggunakan pembelajaran konvensional.
Pada proses pembelajaran model problem based learning disertai teknik kepala bernomor siswa masih ragu dalam memecahkan suatu masalah. Siswa selalu bertanya kepada guru tentang langkah menyelesaikan masalah tersebut pada tiap pertemuan. Siswa tidak mengerti untuk menyelesaikan soal cerita dengan kemampuan sendiri terlebih dahulu. Disamping itu siswa tidak menyelesaikan masalah dengan cara bertahap sehingga siswa tidak menemukan konsep yang diawali dengan permasalahan dari proses pembelajaran problem based learning. Walaupun guru sudah memancing pemikiran siswa melalui petunjuk penyelesaian masalah namun siswa masih ragu untuk mengembangkan pemikirannya kepada kehidupan sehari-hari agar masalah yang diberikan terselesaikan dengan mudah. Penyebabnya adalah siswa sudah terbiasa dengan gaya belajar menggunakan metode ceramah yang mana menerima materi dari guru kemudian mengaplikasikan materi tersebut sehingga untuk menemukan suatu konsep pembelajaran sendiri mereka mengalami kesulitan. Disamping itu siswa terlihat canggung untuk berdiskusi sehingga siswa kurang serius bekerjasama walaupun waktu yang diberikan cukup bagi siswa untuk berdiskusi dan kemampuan siswa terbilang tinggi.

Tabel 1. Perhitungan Rata-Rata $(\bar{x})$, Simpangan Baku (S), Skor Tertinggi $\left(x_{\text {max }}\right)$,Skor Terendah $\left(x_{\text {min }}\right)$ Tes Akhir Kelas Sampel

\begin{tabular}{ccccc}
\hline Kelas & Rata-rata & Simpangan Baku & $\boldsymbol{x}_{\boldsymbol{m a x}}$ & $\boldsymbol{x}_{\boldsymbol{m i n}}$ \\
\hline Eksperimen & 90 & 9,8 & 100 & 66 \\
\hline Kontrol & 87,12 & 11,84 & 100 & 53 \\
\hline
\end{tabular}


Hasil kerja siswa dalam pelaksanaan pembelajaran problem based learning disertai teknik kepala bernomor dapat terlihat dari lembar diskusi pada Gambar 1.

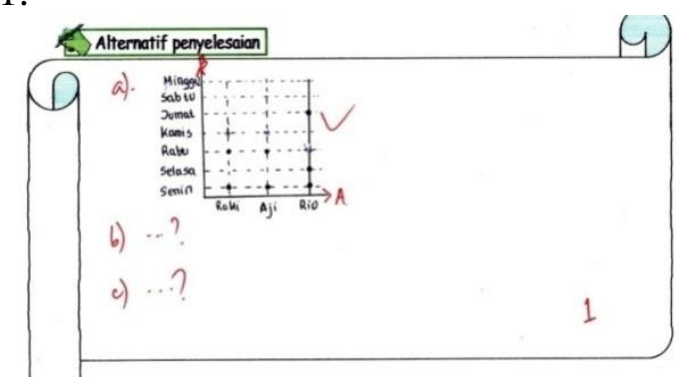

Gambar 1. Lembar diskusi siswa

Berdasarkan gambar 1, terlihat bahwa siswa tidak bisa menganalisa secara keseluruhan permasalahan yang terdapat pada lembar diskusi. Kelompok menyelesaikan masalah tersebut tidak secara bertahap dari data-data yang diketahui sampai perencanaan atau penyelesaian masalah sehingga siswa tidak menemukan konsep dari pembelajaran yang dimulai dengan suatu masalah yang berkaitan dengan kehidupan sehari-hari. Masih ada pertanyaan pada lembar diskusi yang belum dijawab oleh kelompok yaitu soal $1_{\mathrm{b}}$ dan $1_{\mathrm{c}}$.

Proses pembelajaran kelas kontrol dilaksanakan sebagaimana biasanya pelaksanaan pembelajaran di SMPN 7 Padang yaitu menggunakan pembelajaran konvensional. Dimana guru menjelaskan materi di depan kelas dan memberikan latihan sebagai pemahaman materi oleh siswa. Pada pertemuan pertama pembelajaran konvensional untuk kegiatan pendahuluan, guru mengkondisikan siswa untuk siap memulai pembelajaran dengan cara mengambil absen siswa, memberikan motivasi berupa manfaat dari pembelajaran mengenai relasi.

Pada kegiatan inti guru menjelaskan materi relasi dan menyatakan sebuah relasi dengan menggunakan diagram panah, diagram cartesius, dan himpunan pasangan berurutan dengan menggunakan metode ceramah dan tanya jawab. Setelah selesai menjelaskan materi dan tidak adalagi pertanyaan tentang materi relasi kemudian guru memberikan latihan. Pada waktu siswa menyelesaikan soal latihan, guru memantau kegiatan siswa yang mendapatkan kesulitan dalam menjawab soal. Soal latihan dibahas bersama-sama di depan kelas. Guru meminta siswa lainnya untuk saling bertukar buku latihan untuk diperiksa secara bersama. Pada kegiatan penutup salah satu siswa yang terpilih secara acak menyimpulkan materi relasi dan menyatakan sebuah relasi, kemudian guru memberikan pekerjaan rumah dan membahasnya bersama-sama pada pertemuan berikutnya.

Berdasarkan hasil tes akhir siswa kelas eksperimen dan kontrol diperoleh hasil yang tidak jauh berbeda. Berikut contoh jawaban tes akhir siswa kelas eksperimen dan kontrol.

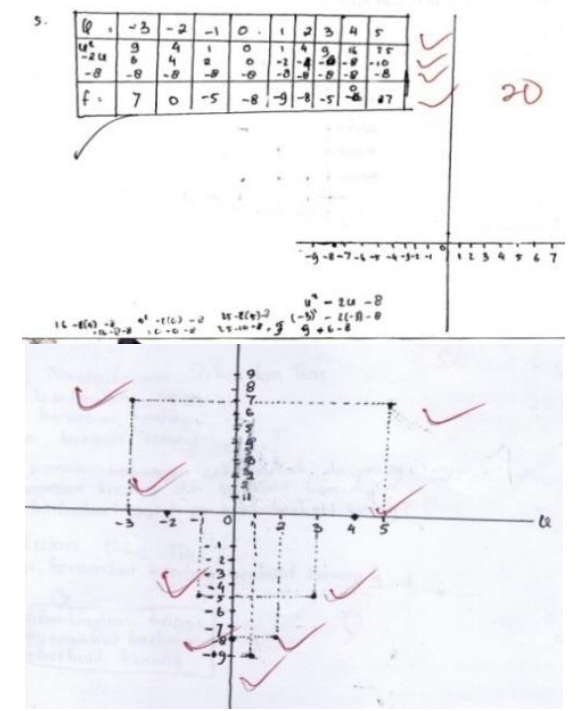

Gambar 2. Hasil tes akhir siswa kelas eksperimen

Berdasarkan gambar 2, siswa sudah mampu menyusun tabel hingga menggambar diagram cartesius berdasarkan domain yang sudah diketahui dengan baik dan benar. Siswa 
menyusun tabel fungsi dengan mengganti nilai variabel $x$ dengan anggota daerah asal sehingga didapatkan nilai $f(x)$ atau anggota daerah kawan sehingga bisa digambarkan grafik fungsi pada koordinat cartesius.

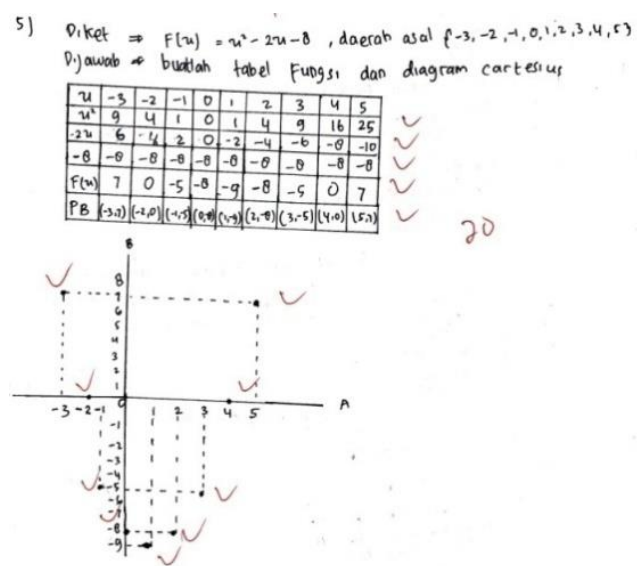

Gambar 3. Hasil tes akhir siswa kelas kontrol

Pada gambar 3, terlihat bahwa siswa menjawab soal dengan baik dan benar. Sama dengan siswa kelas eksperimen, siswa kelas kontrol sudah menjawab soal dengan membuat tabel fungsi berdasarkan nilai fungsi yang diberikan serta mampu menggambarkan diagram cartesius dari nilai $f(x)$ yang didapat.

\section{PENUTUP}

Berdasarkan hasil yang telah dikemukakan dalam penelitian ini, maka dapat disimpulkan bahwa hasil belajar matematika siswa dengan menerapkan model pembelajaran Problem Based Learning disertai Teknik Kepala Bernomor sama dengan hasil belajar matematika siswa yang menerapkan pembelajaran konvensional atau tidak terdapat pengaruh model pembelajaran problem based learning disertai teknik kepala bernomor terhadap hasil belajar matematika siswa.

\section{UCAPAN TERIMA KASIH}

Terbitnya tulisan ini tidak terlepas dari bantuan berbagai pihak, untuk itu penulis ucapkan terima kasih kepada UP3M STKIP PGRI Sumatera Barat sebagai penyandang dana dan pengelola jurnal Pelangi yang telah memberikan saran dan revisi dalam penulisan artikel ini.

\section{DAFTAR PUSTAKA}

Depdiknas. 2001. Penyusun Butir Soal dan Instrumen Penelitian. Jakarta: Depdiknas.

Lie, Anita. 2002. Cooperative Learning (Mempraktikkan Cooperative Learning di Ruang Kelas). Jakarta: PT. Grasindo.

Ngalimun. 2013. Strategi dan Model Pembelajaran. Yogyakarta: Aswaja Pressindo.

Rio. (2015). "Penerapan Metode Problem Based Learning Terhadap Hasil Belajar Matematika Siswa Kelas VII SMPN 2 Linggo Sari Baganti Kabupaten Pesisir Selatan Tahun Pelajaran 2014/2015". Penelitian: STKIP PGRI SUMBAR. 